\title{
The Spanish Craze in the United States: Cultural Entitlement and the Appropriation of Spain's Cultural Patrimony, ca. 1890-ca. 1930
}

\author{
Richard L. KAGAN \\ Johns Hopkins University \\ kagan@jhu.edu
}

Recepción: 18 de diciembre de 2009 / Revisión: 10 de mayo de 2010

Aceptación: 4 de julio de 2010 / Publicación: diciembre de 2010

\begin{abstract}
At the time of war of 1898, the image of Spain in the United States has been traditionally seen as one much influenced by the Black Legend. Notwithstanding the importance of this negative image of Spain, this article suggests that even in that critical historical period there existed another line of thinking that viewed Spain and its culture in a much more positive light. Focusing primarily on topics relating to architecture and art, it further underscores the extent to which Americans of that era sought to incorporate elements of that culture into their own.
\end{abstract}

Keywords: Spain, United States, International Relations, Perceptions, Stereotypes, Culture, Art, Architecture, Hispanism, 1890-1920s.

\section{Hispanomanía en Estados Unidos: pertenencia cultural y apropiación del patrimonio cultural de España, ca. 1890- ca. 1930}

\begin{abstract}
RESUMEN
Tradicionalmente se ha visto la imagen de España en los Estados Unidos durante la guerra de 1898 como muy influida por la llamada 'leyenda negra'. Pese a la importancia de esta imagen negativa de España, este artículo sugiere que incluso en aquel crítico período histórico existió otra corriente de pensamiento que veía a España y su cultura de una forma mucho más positiva. Analizando principalmente cuestiones relacionadas con la arquitectura y el arte, subraya además el interés con que los estadounidenses de la época buscaron incorporar elementos de aquella cultura en la de su propio país.
\end{abstract}

Palabras clave: España, Estados Unidos, relaciones internacionales, percepciones, estereotipos, cultura, arte, arquitectura, hispanismo, 1890-1920s.

SUMARIO: 1. Introduction. 2. American Appreciation of Spanish Architecture and Works of Art. 3. Ethnic Stereotyping: "Authentic" Spaniards in Romantic, Agrarian, Picturesque Spain. 4. The War, U.S. Imperialism, Cultural Entitlement, and the Export of Art. 5. Referencias bibliográficas.

\section{INTRODUCTION ${ }^{1}$}

"But you know what Spaniards are -hospitality itself- and that grand air! By Jove! I don't think any nation in Europe can approach it" 2 . Such was the opinion of

1 This article represents a revised version of an essay originally published in PAYNE, 2010. pp. 25-46.

2 As cited in PISANO, 1983, p. 157. Chase was also one of the first U.S. painters to admire El Greco, advising both New York's Metropolitan Museum of Art and the Philadelphia Museum of Art to purchase paintings by this artist. See Roof, 1917, p. 290. 
William Merritt Chase, the New York artist whose sympathy for Spain, its people, and especially its art epitomizes what can be called the "Spanish Craze" in the United States. The term refers to a particular era in US history when seemingly everything Spanish -art, music, language, literature, architecture, and more- was in vogue. This particular "craze" began in the 1890s, and lasted, with few interruptions until the early 1930s, when it was brought to an abrupt end by a combination of factors associated with the Great Depression, the victory of General Francisco Franco and his Falange Party in Spain's bloody civil war (1936-1939), and changing tastes and fashions in the United States.

This craze, I should add, was not exclusively Spanish in the peninsular sense of the term. Rather it intermingled with various elements of Mexican culture, in large measure because North Americans of that era tended to conflate Spanish and Mexican under the rubric Hispanic, or simply Spanish. Put simply, both Spaniards and Mexicans belonged to the same raza, albeit a raza defined more by "common culture, historical experiences, traditions and language than by blood or ethnic factors"' 3 . Thus Zorro, played by Douglas Fairbanks Sr. in several Hollywood films of the early 1920s, was interchangeably Mexican and Spanish. Similarly, what is known as Spanish Revival architecture - a style popularized across the United States during the 1920 s - was actually a blend of Spanish design elements with others, elaborately decorated doorways for example, that are more properly defined as Spanish Colonial, or Mexican.

Whatever one calls it, the discovery of Spanish art and culture in the United States began at a moment when relations between the two countries were marked by growing political tensions over Cuba that culminated in the short but decisive Spanish-American War of $1898^{4}$. In the years leading up to this conflict, anti-Spanish rhetoric ran high in the United States, especially in the newspapers controlled by William R. Hearst (1863-1951). These papers, notably the New York Journal, drew upon the well-spring of anti-Spanish sentiment known as the Black Legend in order to headline the inhumanity, cruelty, backwardness, and other failings of the Spanish regime in Cuba along with those of the Spanish nation as a whole. Such criticism was also reflected in the 1898 publication of a new English edition of Bartolomé de las Casas, Brief Relation on the Destruction of the Indies, one of the texts that contributed decisively to the early development of the Black Legend. In a bold effort to cash in on the anti-Spanish fervor of the moment, this translation appeared under the sensationalist title of An Historical and True Account of the Cruel Massacre and Slaughter of 20,000,000 People in the West Indies by the Spaniards. Then there was the famous historian of the Spanish Inquisition, Henry Charles Lea, who, in a an article entitled "The Decadence of Spain", attributed that country's defeat by the United

${ }^{3}$ As cited in NIETO - PhILIPS, 2008, p. 177. On the topic of the shared culture of Spain and Spanish America, or what has come to be known as Hispanidad, see SCHMIDT - NowARA, 2006, 2008 and 2010.

4 The literature on Spanish-U.S. relations at the time of the war is immense. Recent summaries include ElorZa - HernándeZ SANDOICA, 1998; OfFnER, 1992 y 1997. For US-Spanish relations after the war, see ElizAdE, 2005 and PAYNe, 2010. 
States to a defective national character distinguished by a "blind and impenetrable pride" and a "spirit of conservatism which rejected all innovation - especially modern industrialism- in a world of incessant change" 5 .

The juxtaposition between this kind of inflammatory criticism, and the proSpanish sentiments of William Merritt Chase is striking. Heretofore, most scholars who have addressed the question of U.S.-Spanish relations in and around the war of 1898 have emphasized the role played by the Black Legend in the configuration of Spain's image in the United States. The importance of the Black Legend cannot be denied -witness the opinion of Henry Charles Lea quoted above-, but as Chase's remark suggests, there existed another line of thinking that represented Spain in a much more positive light. The aim of this essay is to address this apparent contradiction together with the connection between the "Spanish Craze" and the war of 1898.

\section{AMERICAN APPRECIATION OF SPANISH ARCHITECTURE AND WORKS OF ART}

First the "Spanish Craze". What were its dimensions and what forms did it take? Its beginnings are ill-defined, but a possible starting point is 1890, a year marked by the inauguration, in the heart of Manhattan, of a new Madison Square Garden, the second [of four] such amphitheaters known by that name. Designed by the famous New York architect, Stanford White (1853-1906), the most striking feature of the new Garden was not its main building -designed in Italian Renaissance style- but its soaring, three-hundred foot tower, then the second tallest in a city already famous for its skyscrapers. Most early sky scrapers, in New York and other North American cities, were built in neo-classical design and intended to emulate the glory and the power associated with the empires of ancient Greece and Rome. When it came to the Garden, however, White wanted something different, and to do this he modeled the amphitheater's tower upon the Giralda in Seville. Built by the Almoravids in the twelfth century, the Giralda originally served as the minaret of that city's great mosque. That mosque was demolished following Seville's capture by Christians in 1248, but the Giralda, somewhat miraculously, survived, and was soon transformed into a bell tower attached to the sprawling Gothic cathedral erected on the site where the mosque once stood. In the sixteenth century the Giralda acquired a new spire topped by an angel, called the Giraldillo and was symbolically intended to demonstrate the triumph of Christianity over Islam. In his version of the Giralda, White, a notorious womanizer, replaced the angel with a large gilded statue of the naked Diana, the Roman goddess of the hunt. This Diana was a source of scandal, but otherwise White's Giralda elicited nothing but praise. "So big and so beautiful", one critic wrote. "Nothing else in NY has done so much to dignify, adorn, and enliven its neighborhood" 6 . And even though the original Giralda was arguably more "Moorish" than "Spanish", critics were apt to refer to this striking new landmark as a building of Spanish baroque design.

\footnotetext{
${ }^{5}$ As cited in KaGAN, 2002, p. 256.

6 Griswald Van Rennselaer, 1894.
} 
Such a design, moreover, proved infectious inasmuch as White's "Spanish" Giralda triggered a series of copycat structures in various cities across the United States. First in line was Chicago, where the Cold Storage Building erected at the World's Columbian Exposition of 1893 was topped by a smokestack modeled after the tower in Seville7. Then, in San Francisco, the New York trained architect A. Page Brown added a striking Giralda-like tower to the city's new ferry terminal that was completed in $1898^{8}$. Next came Buffalo, NY, where another Giralda replica, festooned with thousands of electric lights, stood as the centerpiece of the PanAmerican Exposition that was held there in 1901. Kansas City and Miami followed in the 1920s, and then Cleveland, where construction of yet another replica of the Giralda, in the guise of the soaring Terminal Tower, was completed in 1928. By this date, the United States boasted no fewer than fifteen replicas of Seville's famous landmark ${ }^{9}$.

But the interest of American developers in buildings of Spanish design did not end with the Giralda. Starting around 1890 the city of St. Augustine, Florida, acquired a series of hotels, suitably named the Ponce de León, the Alcázar and the Córdoba, built in neo-mudéjar-cum-Spanish design. Similar structures soon followed. In 1926, for example, the budding resort town of St. Petersburg, Florida added to its growing array of luxury hotels one called the Royalat, the central part of which was modeled after Seville's Torre de Oro. The Royalat, however, was only one among many Florida hotels and houses built in the so-called "Spanish Revival" style of architecture. Dating from around 1912, this style first made its appearance in southern California where it represented the outgrowth of the earlier "Mission Style", with its roots in the churches and other buildings built by Spanish friars in California and other parts of the American southwest. The first such buildings, simple and relatively unadorned, dated from the 1890s, but the Mission Style soon metamorphosed into a more elegant mixture of Spanish and Spanish colonial architecture in the hands of Bertram Grosvenor Goodhue, the New York architect primarily responsible for the Spanish-style buildings erected in San Diego in conjunction with the Panama-California Exposition of 191510. Within the course of the next decade different iterations of this new Spanish style found their way into domestic architecture across southern California. Notable examples include the so-called "Spanish farmhouse" architecture epitomized by the Casa de Herrero, in Montecito, CA, designed by George Washington Smith in 1924, a style soon to be popularized through such design manuals as Winsor Soule's Spanish Farmhouses and Other Public Buildings (1924). Somewhat more elaborate was the complex of Spanish Renaissance buildings that Julia Morgan designed for William Randolph Hearst in San Simeon, CA. There the main house, named the Casa Grande, was modeled upon the collegiate church of Santa María in Ronda. Meanwhile, Addison Mizner brought Spanish Revival domestic architecture to Palm Beach, Boca Raton, Coral Gables and other cities in south Florida. This style, which blended elements drawn from both

\footnotetext{
${ }^{7}$ Designed by the Chicago architect Franklin P. Burnham, the Cold Storage Building was destroyed by fire on July 10,1893 , only a few months after it was built.

${ }^{8}$ For this Giralda and another that was planned for San Francisco but never built, see LONGSTRETH, 1983.

9 I am currently preparing a study of these American "Giraldas".

10 For this fair, see BOKOVOY, 2005, together with STARR, 1973.
} 


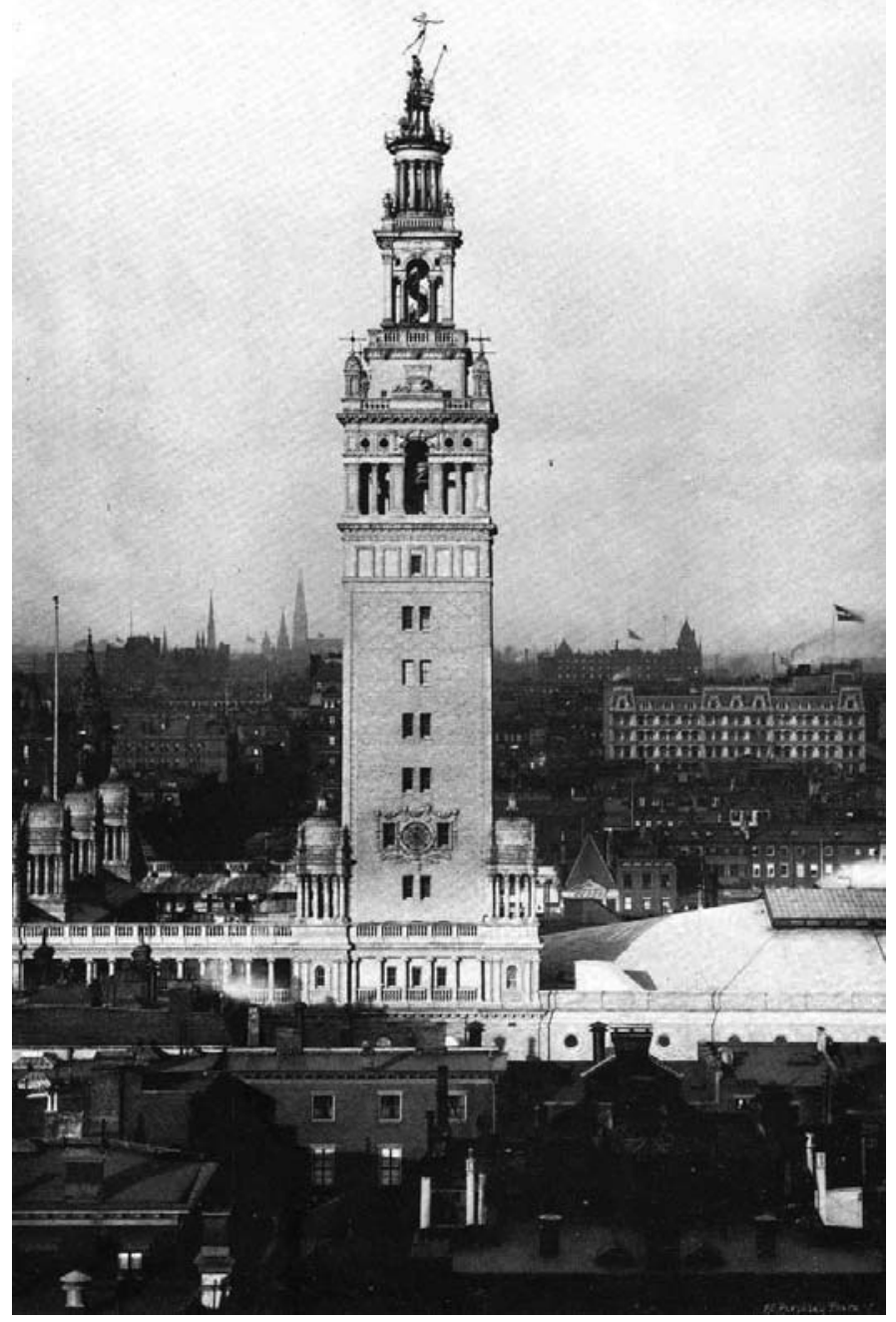

Fig. 1: Madison Square Garden, New York, NY, 1890.

Designed by the famed New York architect, Stanford White, this "Giralda" was the first of many other replicas of Seville' s famous monument that were erected in the United States between 1890 and $1930(*)$.

Spanish and Spanish colonial architecture, soon arrived in Maryland, New York, and other parts of the United States far removed from those regions of the country that were formerly under Spanish dominion. Growing interest in Spanish-themed architecture also sparked a growing demand for Spanish ironwork, tiles, and furnishings of various kinds, much of which was imported directly from both Spain and Mexico, or, whenever necessary, fabricated by domestic producers in accordance with the

${ }^{*} \mathrm{~N}$. de la R.: Las imágenes adjuntas pueden verse con mayor resolución en la versión digital [www.ucm.es/BUCM/revistasBUC/portal]. 
designs appearing in Andrew N. Prentice, Renaissance Ornament and Architecture in Spain (London, 1893; reprint, New York, c. 1925) and Arthur and Mildred Stapley Byne's Spanish Ironwork (1915) and similar titles.

Architecture alone, however, was not enough to contain America's growing enthusiasm for Spanish culture and art. In 1890, the same year in which Manhattan

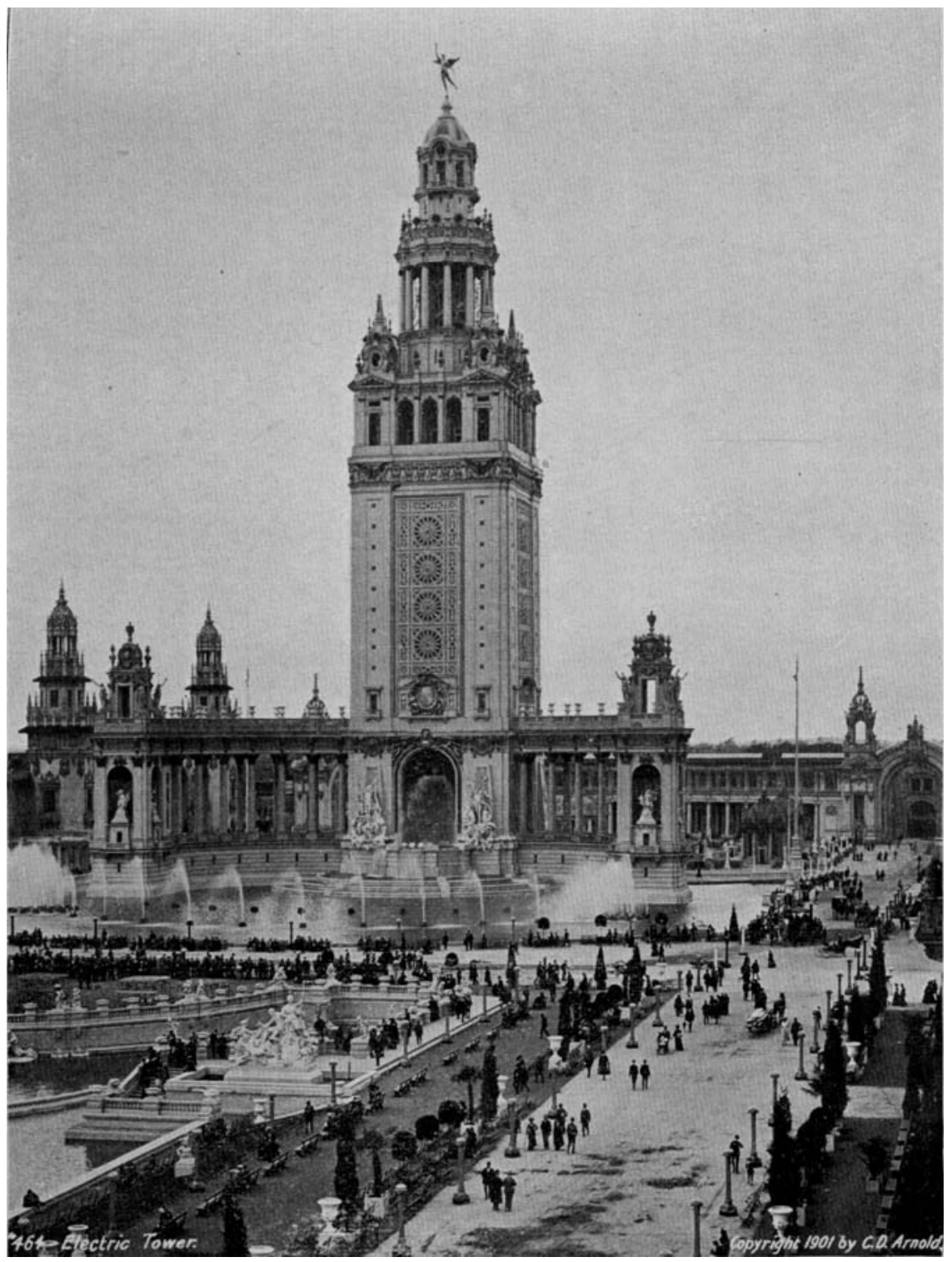

Fig. 2: Electric Tower, Pan-American Exposition, Buffalo, New York, 1901. Brilliantly illuminated by thousands of electric bulbs, this tower represents another example of United States interest in what was described as "Spanish Renaissance" architecture. 
inaugurated its version of the Giralda, a Flamenco dancer known as La Carmencita became something of a celebrity in New York following her performance at a private party in the studio of the artist, William Merritt Chase. That Chase served as Carmencita's New York sponsor was no accident. He was part of a generation of American artists who, starting in the 1860s, journeyed to Spain in search of themes defined as picturesque, the name given that genre of painting that had its roots in the Romantic movement of the early nineteenth century and which, as it developed, embraced crumbling ruins, peasants garbed in traditional dress, and in the case of Spain, gypsies, bullfighters, and the like. The Scottish painter David Roberts (17961864) created the U.S. market for the Spanish picturesque with his large portfolio volumes featuring views of the Alhambra, and scenes of bullfights set against the backdrop of the Giralda ${ }^{11}$. Such were the images of Spain that U.S. artists, starting in the 1850s, would emulate. One of the first was the New York artist Samuel Colman, whose paintings of "sunny" Spain met with favorable critical reviews. Soon, other more famous artists -Thomas Eakins, John Singer Sargent, and Mary Cassatt- followed in Colman's tracks ${ }^{12}$. As for Chase, his initial visits to Spain in 1881 and 1882 led initially to a series of drawings and pictures featuring picturesque themes. But Chase also ook advantage of these visits to discover the work of Diego de Velázquez, an artist whose naturalistic style of painting he endeavored to emulate, especially in portraiture. Chase in fact was so smitten with Velázquez that he announced that he was "the greatest painter that ever lived"13. Such was Chase's interest in this artist that he occasionally clothed his daughter in dresses modeled upon the one the Infanta Margarita wore in Las Meninas ${ }^{14}$. Starting in the 1890s, moreover, Chase led groups of art students to Madrid's Prado Museum so that they, too, could have the opportunity to, as he put it, "revel in Velázquez [...] not forgetting Greco, Goya, and a few more [Spanish artists]", a list that included both Joaquín Sorolla and Ignacio Zuloaga, two contemporaries whose artistic talents he was the first North American to promote 15 .

It is easy to exaggerate Chase's influence on America's artistic tastes, but his enthusiasm for the glories of Spanish art proved infectious. It also helped to change collectors' attitudes about the significance of Spanish art. For most of the nineteenth century most US critics agreed with James Jackson Jarves, whose opinion of the "Spanish school of art", was decidedly low, as the following quote from his 1874 book, Art-Thoughts, readily attests:

We need not look for the poetical or imaginative in Spanish art; seldom for very refined treatment, and never for any intellectual elevation above the actual life out of which it drew its restricted stock-motives. What could be expected of painting in a country where masked inquisitors visited every studio and either destroyed and daubed

11 See, for example, Roberts, 1837.

12 For more on these artists, see Boone, 2007.

13 As cited in WeInBERG, 2003.

14 For Chase and Spanish Art, see PISANO, 1983.

15 For these remarks, see the article AA.VV. "Get Together, Says Mr. Chase to Fellow-Artists", New York Times, 21-V-1905. 
over any details that did not accord with their fanatical scruples? There are admirable points in Spanish painting, but it is not a school of popular value or interest. Besides its two chief names [Velázquez and Murillo] it has no reputation beyond its own locality. The fixed purpose of its priest-ridden work was to stultify the human intellect and make life a burden instead of a blessing ${ }^{16}$.

Such remarks, inspired in large measure by the anti-Spanish prejudice inherent in the Black Legend, began to change in the 1890s, as Royal Cortissoz, Charles Caffin and other New-York based art critics, echoing the ideas of Chase, detected a similarity between the freedom of expression and naturalistic style of Velázquez and

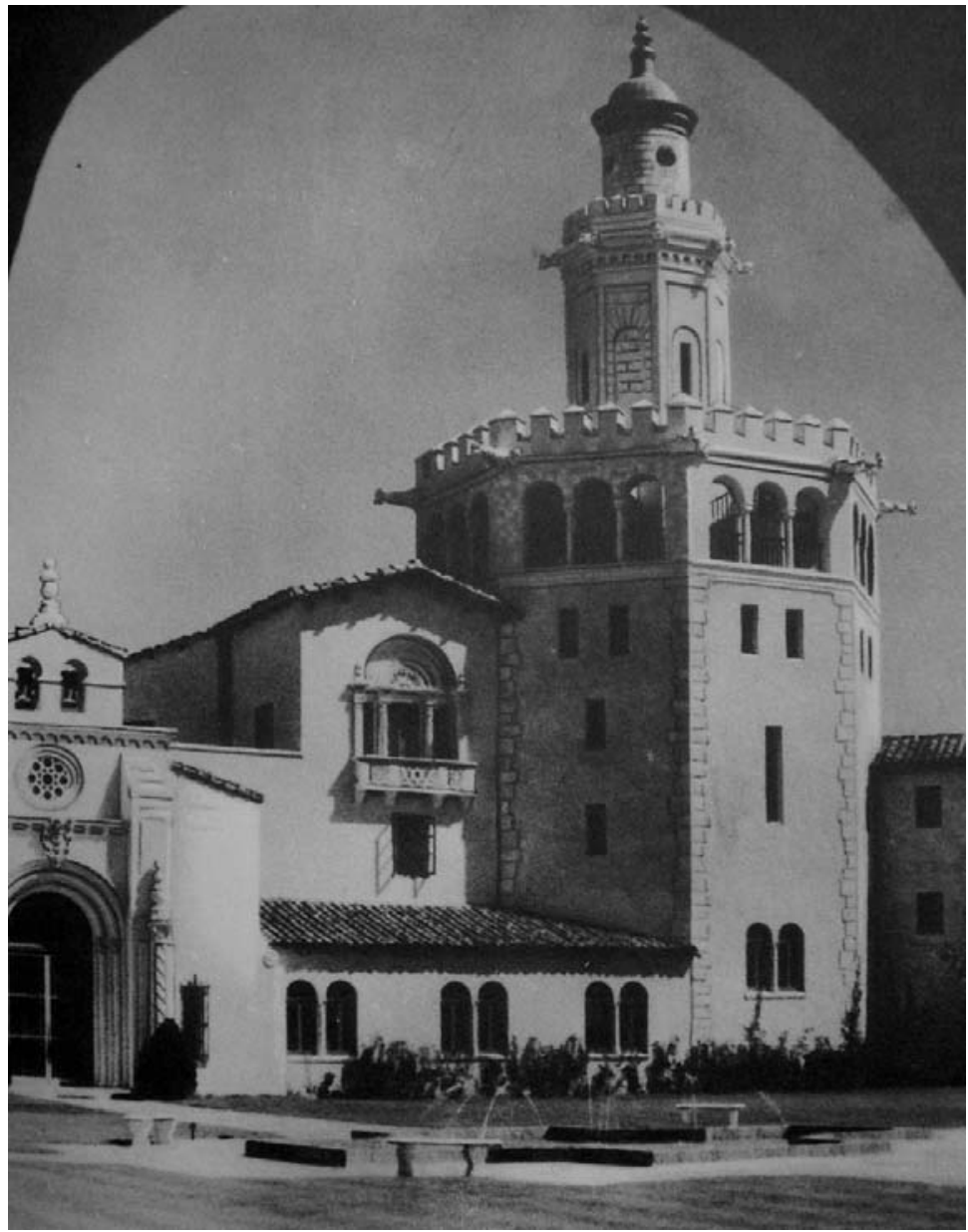

Fig. 3: Hotel Royalat, St Petersburg, Florida, 1925.

Modeled after the Torre de Oro in Seville, this building exemplified on-going United States in Spanish architecture of the Middle Ages and the Renaissance.

16 JARVES, 1871, p. 179. 
El Greco and that of Manet, Degas and the French Impressionists, that is, the artists whose work American collectors of that era were especially eager to acquire.

The rapid diffusion of ideas about the supposed "modernity" of Spanish Old Master art unleashed the artistic equivalent of the Alaska gold rush of 1897. Across the country wealthy collectors competed with one another in a seemingly no-holdsbarred contest to snap up choice examples of works then attributed to El Greco, Goya, Velázquez, etc. I have written elsewhere about the growing demand for Spanish Old Master art ${ }^{17}$, but the key players in this particular (and expensive) game included Isabella Stewart Gardner in Boston; Charles Deering in Chicago; John W. Johnson, P. A. B. Widener, and William Wilstach in Philadelphia; Charles Taft in Cincinnati; Henry and Louisine Havemeyer, Philip Lehman, Benjamin Altman, and Henry Clay Frick in New York; and William Van Horne, an American living in Toronto and one whose predilection for Spanish Old Masters merited an extensive article in the New York Times in $1915^{18}$.

The Times' decision to run an article on Van Horne's Spanish pictures speaks directly to that city's growing fascination with Spanish art. Just as the New York architect Stanford White helped to establish the fashion for Spanish-style building, the nation's growing taste for the artistic and cultural patrimony of Spain contributed to efforts on the part of some collectors to ship whole buildings across the Atlantic. In 1903, for example, William Randolph Hearst made headline news, in both Spain and the United States, when he attempted to purchase an entire Spanish patio of Renaissance design -that of the Casa de Miranda in Burgos-, dismantle it, and then have it shipped and re-assembled in New York. A popular outcry in Burgos prevented this particular sale, although in later years Hearst successfully managed to export to the United States all manner of Spanish artifacts, including two monastery cloisters and the elaborate choir screen from the cathedral of Valladolid which can now be seen on the main floor of New York's Metropolitan Museum ${ }^{19}$.

Another New Yorker with similar interests was Archer Milton Huntington (18701955). To be sure, Huntington's collecting career was markedly different than Hearst's. The latter bought mainly for personal enjoyment; the former to enrich the collections of the Hispanic Society of America, an institution that he founded in 1904 in order to promote Hispanic culture in the United States. Huntington's particular passion was Spanish literature, especially that of medieval and Renaissance. In 1897, for example, just turned twenty six, he translated and published the Poem of El Cid, and in the course of the following years financed the publication of facsimile editions of another forty important works of Spanish literature in the belief that they were relatively unknown and underappreciated in the United States. He also sponsored the teaching of Spanish in New York schools and supported the activities of the famed Instituto de las Españas that Federico de Onís established at Columbia University in $1920^{20}$.

17 KaGAn, en prensa. See also MartínEz RuIZ, 2009.

18 Pictures in AA.VV. "Sir William van Horne's Collection", New York Times, 19-IX-1915.

19 For Hearst's collections, see LEVKOFF, 2008.

20 The best introduction to Huntington, as collector and philanthropist, is CoDDING, 2002. Mitchell Codding is the current director of the Hispanic Society of America. 
Huntington, however, is best known for the Hispanic Society of America, an institution dedicated to "the advancement of the study of the Spanish and Portuguese languages, literature, and history." Originally conceived as a "Spanish museum", Huntington envisioned an institution similar to that of London's British Museum to the extent that it combined a library with selected works of art. But whereas the collections of the British Museum and its Library were universal in scope, the Hispanic Society, as its name suggests, was to be focused exclusively on the Iberian world, Spain in particular. Huntington's institution also aimed at the preservation of Spain's cultural patrimony and, in addition, making that patrimony known to an American audience.

With these goals in mind, Huntington purchased (in 1902) one of Spain's finest private libraries -that of the Marqués de Jérez de los Caballeros- and shipped it to New York, where it later became the nucleus of the Hispanic Society's library. In addition to books and manuscripts, the Hispanic Society housed paintings, ceramics, sculpture and other objects d'art that Huntington and his agents purchased in Europe with an eye towards creating a collection meant to demonstrate what he once referred to as "the soul of Spain"21. Opened to the public in 1908, the Hispanic Society attracted vast crowds to its NeoClassical building in uptown New York, and the crowds returned in the following years for exhibitions of paintings by Sorolla and Zuloaga, the first of Spain's "modern" artists to acquire a large following in the United States. The success of

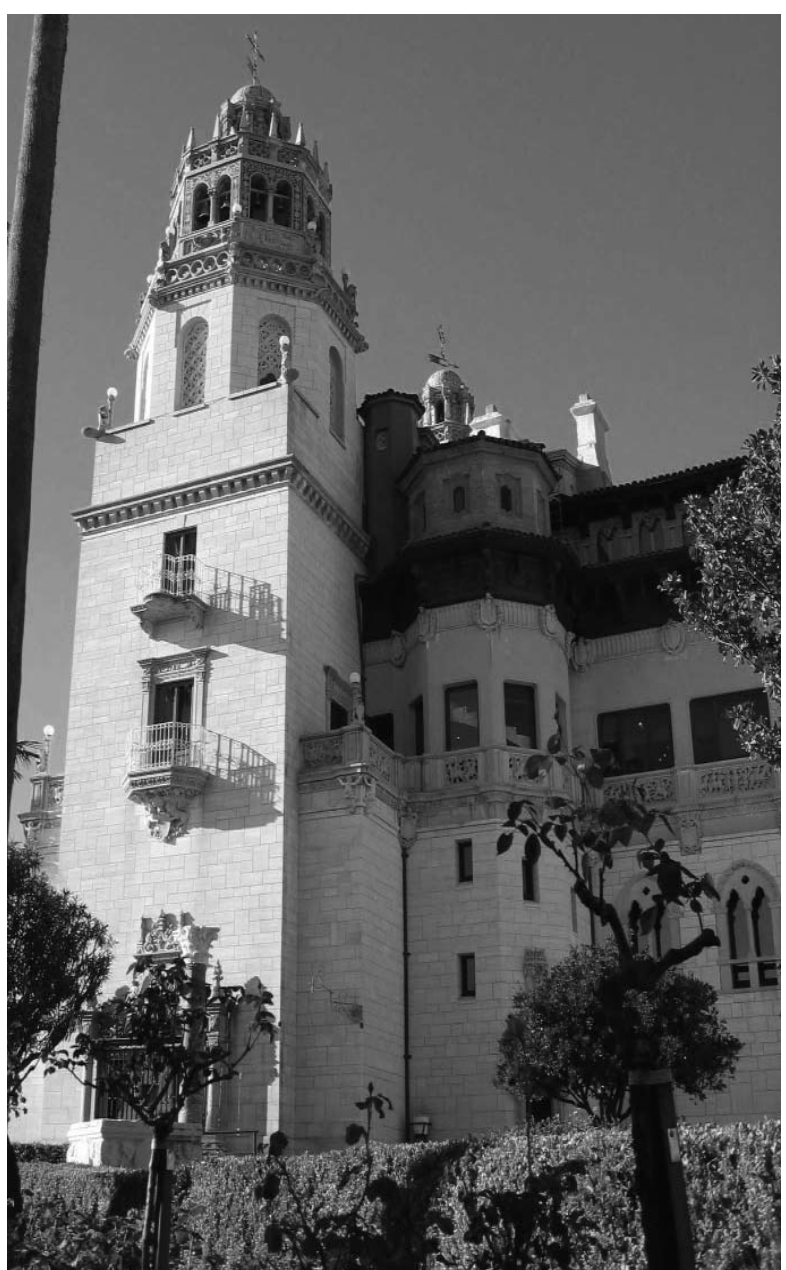

Fig. 4: Casa Grande, San Simeon, California, ca. 1925.

Designed by Julia Morgan for the US newspaper magnate, William Randolf Hearst, the Casa Grande, part of the so-called Hearst Castle, was modeled after the collegiate church in Ronda.

21 Cited in Codding, 2002, p. 154. 
these exhibitions led one New York art dealer to comment that "Spain sank low in our defeat of her, she has replied with the lightnings of art"22.

\section{ETHNIC STEREOTYPING: NATURAL, "AUTHENTIC" SPANIARDS IN ROMANTIC, AGRARIAN, PICTURESQUE SPAIN}

The comment is apt, and directly relevant to the question posed at the outset of this essay: the relationship between the Spanish American War of 1898 and America's enthusiastic embrace of a culture it previously held at arm's length. A fully-documented answer to this query cannot be offered within the constraints of this article, but among the factors contributing to this development was the continuing pervasive influence of the famous New York author, Washington Irving (17831859). Irving's interest in Spain began with his decision to write a biography of the famous mariner Christopher Columbus, using books and manuscripts that were available only in Madrid and Seville. Irving embarked on this particular endeavor during the winter of 1825-1826, but within a few months he broadened his curiosity to include the whole of Spain's complex history, especially that of al-Andalus. Irving's Life and Voyages of Christopher Columbus appeared in 1828, and was quickly followed by such works as the The Chronicles of the Conquest of Granada (1829) and the collection of short stories entitled Tales of the Alhambra (1832), an often reprinted volume whose romantic vision of Spain was arguably instrumental in altering Spain's image in the United States by portraying it as a sunny, picturesque country populated mainly by gypsies, toreros, colorful bandits, and other characters reminiscent of those found in Beaumarchais's Barber of Seville 23 . Irving was by no means the only writer who contributed to this image of sunny Spain -others included Alexander Slidell Mackenzie, Caroline Cushing and Henry Wadsworth Longfellow, along with Teóphile Gautier in France and Richard Ford in England-, but the overall result was a picture of a quasi-exotic yet accessible country, a mustsee for any American interested in experiencing the picturesque ${ }^{24}$.

During Irving's lifetime -he died in 1859- the number of Americans who visited Spain were relatively few. But what began as a trickle soon developed into a steady stream. Precise numbers are scarce, but the turning point appears to have been the 1870s, the decade that marked the opening of a direct rail link between Paris and Madrid, as well as the beginning of a prolonged period of relative political stability in Spain brought about by the restoration of the Bourbon monarchy in 1875. This increase is partly reflected in the "Libros de Visitas" of the Prado Museum, a mecca for foreigners visiting Spain, many of whom identified themselves as tourists, a neologism that separated these travelers from those with commercial and political con-

22 Ibidem, p. 161.

23 Irving and other nineteenth-century U.S. hispanists may be approached through the essays in KAGAN, 2007.

24 For U.S. travelers to nineteenth-century Spain, see GIFRA-ADROHER, 2000; KAGAN, 2009. Other studies include SÁNChez Mantero, 2001; García-Montón - García-Romeral, 2000 and Gamir SANDOVAL, 1954. 
cerns ${ }^{25}$. Increases in the number of Americans visiting the Prado and other Spanish attractions and places - the standard itinerary was Paris to Madrid, then south toward Toledo, Granada, Córdoba and Seville- also reflected the start of America's fabled

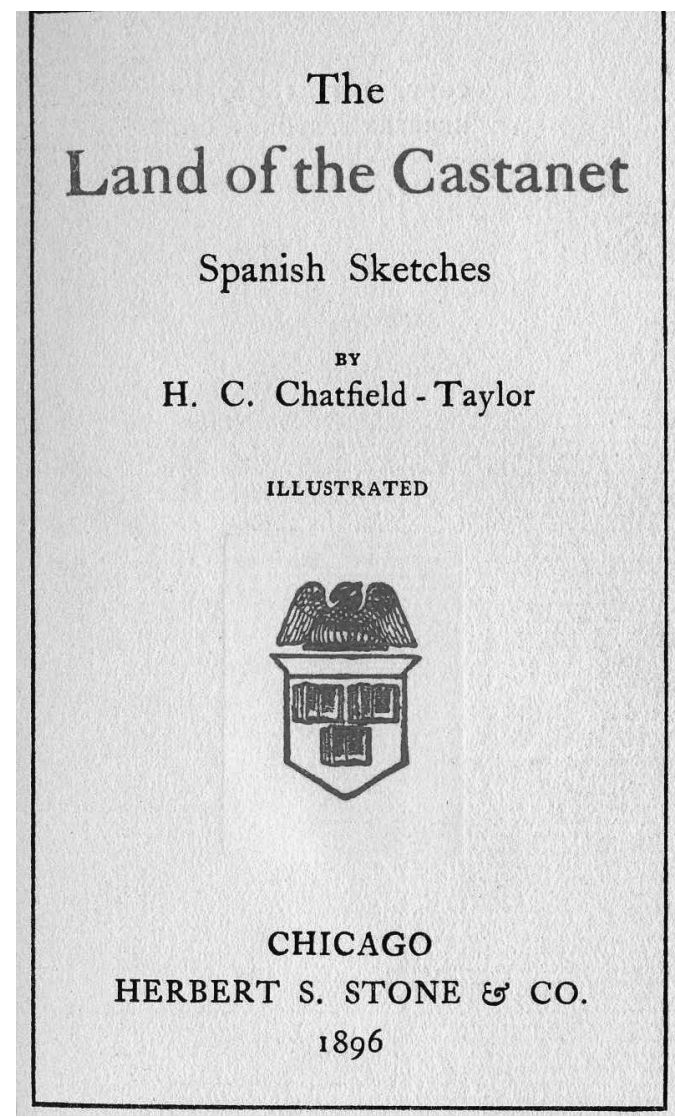

Fig. 5: Title Page, The Land of the

Castanet. Spanish Sketches (1890).

This book was one of many publications that helped to create a wholly romanticized view of Spain and its people in the United States during the later part of the 19th Century.
Gilded Age, an era of dramatic economic growth in the United States and one that increased the number of Americans with the wealth and the inclination to visit Europe. It has been estimated that in 1880 about 50,000 Americans visited Europe each year. By 1900 that number reached 125, 000 and by 1913 roughly $250,000^{26}$. It is difficult to know how many of these travelers included Spain on their itineraries, but interest in the country was clearly increasing.

Another attraction was the vision of Spain as a traditional, agrarian society relatively untouched by industrialization and modernization, two forces that many cultivated Americans, especially those influenced by the medievalism associated with the famed British writer John Ruskin, looked upon with dismay. Ruskin's disciples in the United States included Henry Adams (1838-1918) and Charles Eliot Norton (1827-1908), both of whom shared a romanticized view of the Middle Ages as a "vital, collective, and organic culture" that contrasted radically with the "anomic, dehumanized industrial world" which they themselves inhabit$\mathrm{ed}^{27}$. Exponents of medievalism also regarded the art and architecture of the Middle Ages as authentic to the extent they were seen as genuine expressions of the human spirit as opposed to the artificial products of machines.

25 These registers, known also as the "Libros de Apuntes", begin in the 1830s and end in the 1870 s. They can be consulted in the archive of the Prado Museum. They await detailed study. For an introduction to their contents, see KAGAN, 2007.

26 Hoganson, 2007, p. 171.

27 FreEdMAN - SpIEGEL, 1998, p. 680, together with LeARS, 1981. 
In this context, Spain, with its reputation for backwardness, struck many Americans to be authentic in ways that other European countries were not. The country, of course, was changing, but U.S. publishers could not get enough of books and articles that represented Spain as if it were a country caught in a time warp and where scenes reminiscent of the Middle Ages were still readily visible. The list of the publications offering this image of Spain is far too long to enumerate here, but fairly typical is the essay, "Street Life in Spain", that appeared in Century Magazine in 1889 accompanied by illustrations by William Merritt Chase. The author, Susan Carter, Director of Painting at New York's Cooper Union, drew upon well-established racial tropes to describe what she viewed as the timeless, unchanging character of the "Spanish type". "One is constantly amused and surprised", she wrote,

[...] to see that habits and manners of the Spanish people, as well as their faces, are precisely the same to-day as when Velázquez painted his sharp wiry faces in the Buveurs or Murillo his dark children ${ }^{28}$.

Similar ideas could be found in H. C. Chatfield-Taylor's The Land of the Castanet. Spanish Sketches (1896), a book that prompted one irate Spanish reviewer to comment that such a title was the equivalent of calling the United States "the land of bacon"29.

The reviewer is correct, but The Land of the Castanet. Spanish Sketches and similar books both reflected and helped reinforce a cultural stereotype that ignored the nation's emergent industries in the Basque Country and Catalonia, let alone the nascent anarchist movement that culminated in Barcelona's Tragic Week in 1900. They focused instead on the country's most picturesque elements -gypsy dancers, dashing matadors, peasants stretched for a siesta in the afternoon sun- while virtually ignoring the rest. Yet the stereotype had its uses, and at the very least served to generate interest in Spain just at a time when many Americans, together with Adams and Norton, believed that the forces of industrialization were rapidly undermining the simpler, agrarian values that they associated with the greatness of the United States. One such individual was the Harvard professor James Russell Lowell, who, in the course of a visit to Spain in 1878, wrote to a friend: "You can't imagine how far I am away from the world here $-\mathrm{I}$ mean the modern world. Spain is as primitive in some ways as the books of Moses and as oriental". As for the people, Lowell echoed Irving when he wrote that "they are still orientals to a degree one has to live among them to believe [...] they don't care about the same things that we are fools to believe in [ such as business and accounting]". This opinion led Lowell to conclude that hard-working Americans preferred the economic benefits associated with the "millpond," while Spaniards preferred the peaceful pleasures derived from the "brook" 30 .

Today's readers are apt to take issue with the condescending tone of Lowell's remarks, but it is important to recognize that Lowell, together with other Americans

28 CARTER, 1889, as cited in BOONE, 2007, p. 170.

${ }^{29}$ For the Spanish response to this book, see SÁNCHEZ MANTERO, 1994, pp. 38-39.

30 Lowell to Thomas Hughs, 17-XI-1879, and Lowell to W.D. Howells, 2-V-1879, cited in NoRTON, 1893, 2, pp. 235 and 241. 
of his generation, were ready to put the Black Legend behind them and to look upon Spain in a more positive light. Of particular importance here was the emergence, starting again in the closing decades of the nineteenth century, of the idea of Spain as a country whose people had contributed enormously to the march of civilization in the New World. The seeds of this idea can be traced back to the famed Boston historian William Hickling Prescott (1796-1859), especially his best-selling History of the Conquest of Mexico (1843) which credited Spain with the overthrow of the semi-civilized Aztecs and advancing the cause of progress and Christianity in the Americas. The next major historian to address this theme was Hubert Howe Bancroft, who, writing in 1888, eulogized life in Spanish California as nothing less than "a long, happy holiday" 31 . Charles Lummis (1859-1928), the socalled "apostle of the SouthWest" expressed similar sentiments. A student of Norton's at Harvard, in the 1880s Lummis moved to California where he

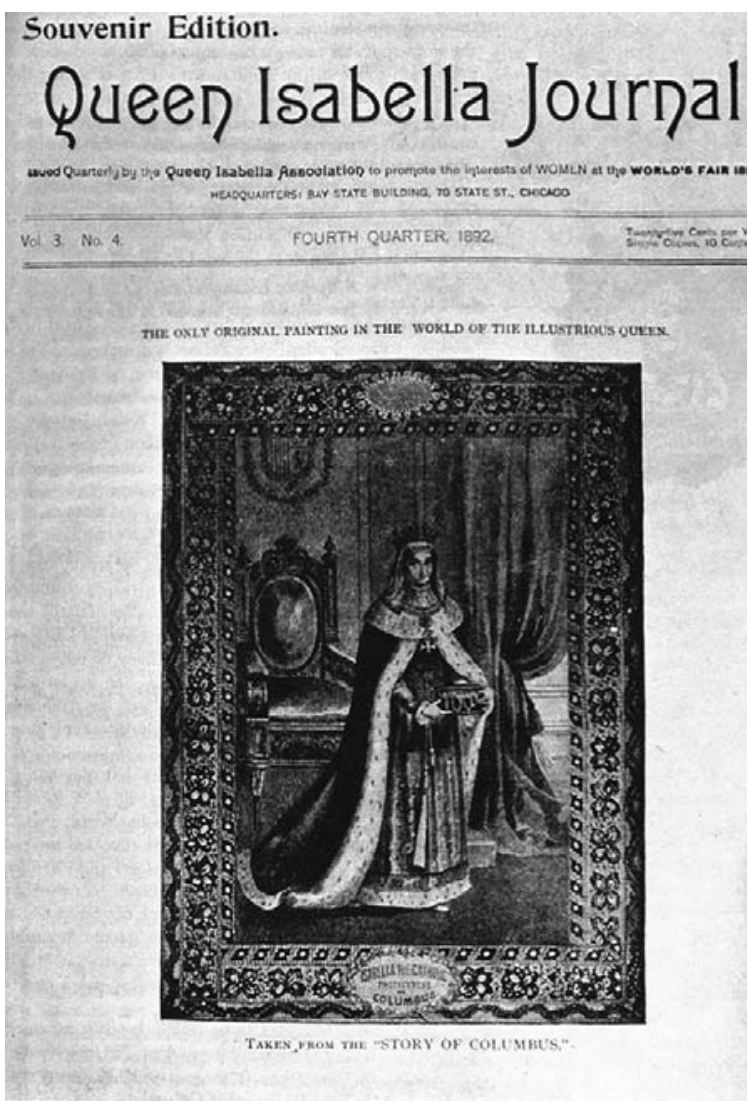

Fig. 6: Queen Isabella Journal (1892).

This short-lived journal, published in accordance with Chicago's Columbian Exposition of 1893, was inspired by the Queen Isabella's support for Christopher Columbus. Its aim was to highlight the role of women in the progress of civilizartion. devoted himself to writing books and articles highlighting diverse aspects of the region's history and culture. His most influential publication was The Spanish Pioneers ( $1^{\text {st }}$ edition, 1893), which argued that the culture and civilization of the United States owed as much to Spain's conquistadors and missionaries who settled the Southwest as to the English men and women who settled the East, if not more. Turning his back on the Black Legend, Lummis went so far as to characterize what he termed Spanish "pioneering" in the Americas as both "humane and progressive" in addition to "the most marvelous feat of manhood in all history" 32.

31 As cited in Weber, 1992, p. 341.

32 Lummis, 1912, pp. 12 and 23. For more on Lummis, see Nieto-PhiLIPs, 2008, chap. 4. 
Spain and the memory of its past fared equally well in the novel Ramona, first published in 1884. The work of Helen Hunt Jackson, a staunch defender of indigenous rights, this novel, set in California at the start of the nineteenth century, represented the Spanish Mission in wholly utopian terms, a special "place of grace" where kindly friars taught natives the benefits of work, religion, civilization and the arts. A runaway best-seller from the very start, Ramona's popularity helped spark efforts to refurbish California's crumbling missions together with a campaign to restore the famed "camino real" that linked San Diego in the south with San Francisco in the north. Meanwhile, Ramona inspired the New York architect Stanford White in 1887 to design the Ramona Indian School for Santa Fe, New Mexico. In the end, the school was never built, but in an effort to bolster the town's image, the city fathers incorporated festivities honoring Santa Fe's Spanish heritage into the annual Fourth of July celebrations ${ }^{33}$. Ramona's influence was also in evidence in La Fiesta, an annual celebration inaugurated in Los Angeles in 1894 and designed to demonstrate that city's Spanish origins, and fifteen years later in San Francisco's La Portola, a celebration in honor of Gaspar de Portolà y Rovira (1761-1776), the Spanish army capitan credited with leading the first European overland expedition to sight that city's famous bay in $1769^{34}$.

Similar ideas emerged, not coincidentally, at the World's Columbian Exposition celebrated in Chicago in 1893. Attended by hundreds of thousands of visitors, the fair aimed at demonstrating the wealth, power and importance of the United States. Yet it also represented North Americans as the direct heirs of Columbus and the valiant Spaniards who settled the New World. Monumental sculptures featured the famous mariner, a replica of the Franciscan Monastery at La Rábida placed numerous objects associated with Columbus and the court of the Catholic Monarchs on public display, and a special commemorative quarter bore a likeness of Queen Isabella. There was even a quarterly journal named in her honor that was designed to promote the interests of the women who attended the fair ${ }^{35}$.

Spain came off equally well in Buffalo, New York, which, starting in the 1890s, laid plans for a Pan American Exposition designed to "celebrate the supremacy of the United States in the Western hemisphere" as well as to promote the essential unity of the Western hemisphere. "This to be an American Exposition-North, South and Middle" as one of its organizers wrote. When it came, however, to the fair's architecture, the organizers adopted what was essentially a nativist stand when they decided upon a Spanish theme in the belief that this particular style best embodied the idea of "America". The war of 1898 postponed the opening of this exposition until 1901, but the anti-Spanish rhetoric occasioned by this conflict did nothing to alter this architectural scheme which, as noted earlier, centered a brightly-illuminated replica of the Giralda. As for the fair's Spanish Renaissance design, one commentator laud-

33 For Santa Fe's recovery of its Spanish past, see WiLSON, 1997, and Lovato, 2006.

34 For La Fiesta, see Deverell, 2004, and Kropp, 2006. For La Portolá, see GlassBerg, 2001, p. 62.

35 Queen Isabella's Journal is briefly discussed in FlEMING, 1906, p. 793. For the Spanish presence at the fair, see BANCROFT, 1893, pp. 655-662, 910-912, and 971. 
ed that particular style in the belief that "it symbolizes our welcome to the genius of the Latins to mingle their strains with the genius of the Anglo-Saxons"36.

One can readily object to the racist terminology this commentator employed, but the observation is important to the extent that it suggests that the war of 1898 did little to arrest the momentum of the Spanish craze. The fair's architecture is also important to the extent that it represents a relatively early expression of Hispanidad, one that was soon to be reiterated at the Panama-Pacific International Exposition held in San Francisco in 1915, along with San Diego's Panama-California Exposition, whose Spanish-themed buildings can still be seen in that city's Balboa Park.

\section{THE WAR, U.S. IMPERIALISM, CULTURAL ENTITLEMENT, AND THE EXPORT OF ART}

As for the relationship between the war of 1898 and the nearly contemporaneous "Spanish Craze" in the United States, what seems certain is that the conflict did little to dampen American enthusiasm for Spanish art and culture. In fact, the structural causes and consequences of this war actually appear to have contributed to the strength and momentum of the "craze", partly because it served to focus new attention on Spain and its historic relation to the United States. The partisans of that "splendid little war", in the oft-cited words of the then U.S. Secretary of State (and former U.S. ambassador to Spain) John Hay, interpreted their country's victory in various ways. Some regarded it as a victory for democracy over monarchy. Others saw it as a victory for Christianity, defined in wholly Protestant terms over Catholicism, as well as a powerful demonstration of the superiority of the AngloSaxon race, as embodied in the United States, over that of the Latins, as symbolized by Spain. Not all Americans agreed with this view, and the voices of the so-called anti-expansionists -they included Charles Eliot Norton- echoed through Congress prior to the vote ratifying the Treaty of Paris, the accord that officially ended the conflict and obliged Spain to cede its overseas colonies to the United States. This vote, however, was wholly in keeping with President William McKinley's notion that America's triumph in the war with Spain represented nothing less than "a victory for God and civilization"37.

Such ideas were consistent with ideas about America's "Manifest Destiny", or the belief that the country was obliged to continue its territorial expansion and, in doing so, bring the benefits of what it understood as civilization to other parts of the world. As is well known, Manifest Destiny harbored within it the concept of AngloSaxon/Anglo-American cultural and racial superiority. Manifest Destiny also incorporated notions of cultural entitlement, or the idea that the United States, as it expanded its frontiers, both economic and geographic, had the right, possibly even the obligation, to enrich its own culture and traditions with that of other nations with which it came into contact. Such ideas can be found in the writings of Henry James

36 ARNOLD, 1901, pp. 28-30.

37 As quoted in a speech delivered on October 21, 1898 in Columbus, Ohio; see McKINLEY, 1900, p. 152. 
(1843-1916), an author whose work is synonymous with the Gilded Age. A New Yorker who lived much of his life in Europe, James wrestled with the idea of what it meant to be an American, a topic he addressed in both in his private correspondence as well as his novels. As early as 1867, for example, he wrote:

I think to be an American is an excellent preparation for culture [...] we can deal freely with forms of civilisation not our own; we can pick and choose and assimilate and in short (aesthetically etc.) claim our property wherever we find $\mathrm{it}^{38}$.

James subsequently developed this theme in his first major novel, Roderick Hudson (1875) where he espoused the idea that collecting, whatever its aesthetic pleasures, was not only socially useful but also patriotic; something, in other words, in which every red-blooded American with the means to do so should engage. James's novel centers on the character of Roland Mallet, who, as James describes him, "was extremely fond of all the arts and had an almost passionate enjoyment of pictures" 39 . As a good citizen, Mallet believed he should go abroad and secretly purchase valuable specimens of European art then present them to an American city. To be sure, not all collectors were so altruistic, but in creating Mallet as the central character of his novel, James helped popularize the idea -call it "art for the nation"- that collecting, more than an individual caprice, was also a patriotic act to the extent that it served to enrich the artistic and cultural patrimony of America as a whole. From there it was only a short

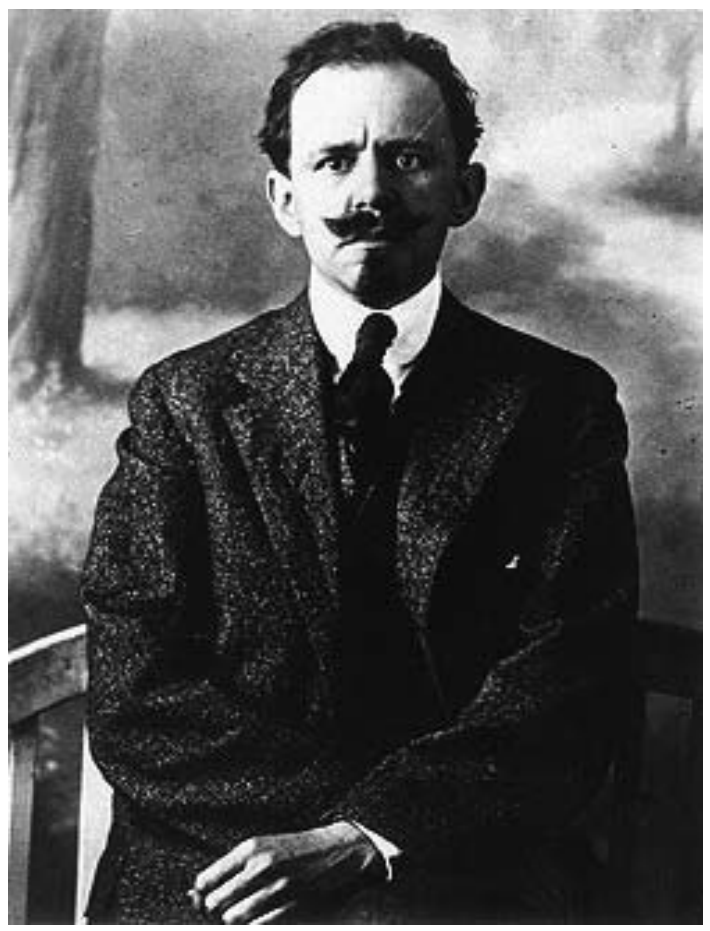

Fig. 7: Arthur Byne (1884-1935).

An American antiquarian based in Madrid, Byne, together with his wife, Mildred Stapley, specialized in the he export of Spanish art objects to wealthy collectors based in the United States. He died in an automobile accident on the outskirts of Madrid. step to the attendant idea that collectors had the responsibility to bequeath their private collections to public museums, a practice that quickly emerged as one of the defining elements of American society in the course of the Gilded Age ${ }^{40}$.

38 Henry James to Thomas Sargent Perry, 20-IX-1867, as published in WALKER - ZACHARIAS, 2006, vol. 1 p. 179.

39 JAMES, 1875, chap. 1, p. 4.

40 For more on the patriotic aspects of collecting, see HARRIS, 1984, p. 137. 
From this perspective, the victory of the United States in the war of 1898, more than a simple affirmation of American power, also represented a golden opportunity -one that invited Americans to appropriate the patrimony of a country whose art and whose architecture they were just learning to appreciate. In the wake of defeat, Spain appeared to be weak and impoverished, and from the perspective of avid collectors such as Hearst, hardly in a position to preserve, let alone appreciate, its many artistic and architectural treasures. Better that such treasures be entrusted to his care. Even, Huntington, the self-proclaimed champion of Spain in the United States, was seemingly of the opinion that Americans interested in Europe, rather than reside there, should "go there and get their culture if possible" 41 . Huntington's use of the verb "get" in this context is somewhat vague, but one of the aims of the collection he assembled at the Hispanic Society was to preserve Spain's artistic heritage and also provide a continuous record of Spanish achievement before the country succumbed to the destructive forces associated with the modern industrial world. In this sense, the Society was Huntington's personal refuge, and his collecting in line with other US collectors who believed that it was their patriotic obligation to acquire -rescue might be another word- Europe's art objects, restore and display them, and in doing so, enrich their country and culture as a whole. For this reason, just as the United States was discussing the terms of the Treaty of Paris with Spain, articles in the New York Times suggested that the government, in lieu of territorial concessions, ought to have contents of the Prado Museum shipped to New York ${ }^{42}$.

In the end the final treaty contained no such provision, but the suggestion itself was wholly in line with contemporary ideas about cultural entitlement together with the notion that the United States could better preserve Spain's cultural patrimony than Spain itself. Hearst summarized this line of thinking when he defined Spain as a "tired, worn out monarchy" and a waiting to be "ravaged" by individuals such as himself ${ }^{43}$. It is also worth noting that the New York Times adopted a similar position in 1910 when it reported on Hearst's frustrated attempt to export the patio of the Casa de Miranda to the United States. Striking a decidedly nationalist note, the newspaper reported that:

It is good for the people of Burgos to be alive to the worth of its treasures [...] foreign folk [that is, Spaniards] ought to be grateful to the American collectors [...] for stirring up their pride ${ }^{44}$.

In the end, such ideas were consistent with those of other Americans with interests in Spanish art, and it certainly coincided with those of the art and antiques dealers who specialized in the export of Spain's treasures abroad. Notable in this regard was Arthur Byne (1884-1935), an American architect who initially traveled to Spain

41 As cited in CoDding, 2002, p. 163.

42 AA.VV. "Wealth Spain Still Has", The New York Times, 10-IX-1898.

43 In a letter written to his mother in April, 1905, on the verge of a visit to Spain, Hearst writes: that "[we] will burst through the Pyrenees into Spain and ravage the country. How does that strike you?" See Bancroft Library, Berkeley, CA: Phoebe Hearst Collection, Box 7, n. 2.

44 AA.VV. "Pride of Burgos", The New York Times, 3-XI-1910, p. 8. 
in 1910 under the auspices of the Hispanic Society in order to photograph and catalogue its medieval monuments. Byne soon emerged as one of the leading experts in this particular field, and his expertise was even recognized by the Spanish government, which honored him with the title of Knight Grand Cross in the Order of Alfonso XII in 1927. At the same time, Byne capitalized on his expertise to become an important antiques dealer, exporting all manner of objects -furniture, ironwork, choir stalls, inlaid wooden ceilings, and more- to numerous clients in the United States. Such in fact was Byne's interest in and passion for this particular enterprise that, in a 1934 letter addressed to Julia Morgan, he admitted that "My only role in life is taking down old works of art, conserving them to the best of my ability and shipping them to America" ${ }^{45}$. An isolated statement, perhaps, but one that also underlies much of the "Spanish Craze", especially in the years following the victory of the United States in the war of 1898.

\section{REFERENCIAS BIBLIOGRÁFICAS}

ARNOLD, Charles Dudley

1901 The Pan-American Exposition. Illustrated. Buffalo (NY).

BANCROFT, Hubert Howe

1893 The Book of the Fair. Chicago - San Francisco. The Bancroft Company. Bokovoy, Matthew F.

2005 The San Diego World's Fairs and Southwestern Memory 1880-1940. Albuquerque. University of New Mexico Press.

Bokovoy, Matthew F. - StARR, Kevin

1973 Americans and the California Dream. New York. Oxford University Press.

Boone, Mary Elizabeth

2007 Vistas de España: American Views of the Art and Life in Spain, 18601914. New Haven - London. Yale University Press.

CARTER, Susan

1889 "Street Life in Spain". Century Magazine. New York. nº 39 (Nov.), pp. 32-41.

CoDDING, Mitchell

2002 "Archer Milton Huntington. Champion of Spain in the United States". In Kagan, Richard (ed.). Spain in America. The Origins of Hispanism in the United States. Champagne-Urbana (ILL). University of Illinois Press. pp. 142-170.

DEVERELL, William

2004 White-Washed Adobe: The Rise of Los Angeles and the Remaking of its Mexican Past. Berkeley - Los Angeles. University of California Press.

ElizADE, María Dolores

2005 "Las relaciones entre España y los Estados Unidos en el umbral de un nuevo siglo". En Delgado, Lorenzo - ElizAdE, María Dolores (eds.). España y los Estados Unidos en el siglo XX. Madrid. CSIC, pp. 19-56.

45 Letter of Arthur Byne to Julia Morgan, 15-I-1934, as cited in Holmes Boutelle, 1988, p. 247. 
Elorza, Antonio - Hernández SANDOICA, Elena

1998 La Guerra de Cuba (1895-1898). Historia politica de una derrota colonial. Madrid. Alianza.

EgeA FernándeZ-Montesinos, Alberto (coord.)

2009 Viajeras anglosajonas por España. Una antología. Sevilla. Centro de Estudios Andaluces.

FLEMING, Herbert E.

1906 "The Literary Interests of Chicago". American Journal of Sociology. Chicago. $n^{\circ} 11$, pp. 499-531.

FrEEDMAN, Paul - LEARS, T. Jackson

1981 No Place of Grace. Anti-modernism and the Transformation of American Culture, 1880-1920. New York. Pantheon Books.

FreEdMan, Paul - Spiegel, Gabrielle M.

1998 "Medievalisms Old and New: The Rediscovery of Alterity in North American Medieval Studies". American Historical Review. Washington. $\mathrm{n}^{\mathrm{o}}$ 103: 3, pp. 677-701.

GAMIR SANDOVAL, Alfonso

1954 Los viajeros ingleses y norteamericanos en la Granada del siglo XIX. Granada. Universidad de Granada.

García-Montón, Maria Isabel - GarcíA-Romeral, Carlos

2000 "Viajeros americanos en Andalucía durante los siglos XIX y XX". Revista Complutense de Historia de América. Madrid. n 26, pp. 261-280.

GIFRA-ADROHER, Pere

2000 Between History and Romance: Travel Writing on Spain in the Early Nineteenth Century. Madison (NJ). Fairleigh Dickinson University Press.

GLASSBERG, David

2001 The Place of the Past in American Life. Amherst (MA). University of Massachusetts Press.

GRISWALD VAN RENNSELAER, Marianna

1984 "Madison Square Garden”. Century Magazine. New York. nº 47: 5, pp. 732-747.

HARRIS, Neil

1984 Cultural Excursions. Marking Appetites and Cultural Tastes in Modern America . Berkeley - Los Angeles. University of California Press.

Hoganson, Kristin L.

2007 Consumers' Imperium. The Global Production of American Domesticity 1865-1920. Chapel Hill. University of North Carolina Press.

Holmes Boutelle, Sara

1988 Julia Morgan Architect. New York. Abbeville.

JAKSIC, Iván

2007 The Hispanic World and American Intellectual Life, 1820-1880.

JAMES, Henry

London. Palgrave Macmillan.

1875 Roderick Hudson. New York. J.S. Osgood. 
JARVES, James Jackson

1871 Art Thoughts. The Experiences and Observations of an American Amateur in Europe. New York. Hurd and Houghton.

KAGAN, Richard L.

2002 Spain in America. The Origins of Hispanism in the United States. Champagne-Urbana (ILL). University of Illinois Press.

2007 "Yankees in the Prado: A Historiographical Overview". Boletin del Museo del Prado. Madrid. vol. XXV. no43, pp. 32-45.

(en prensa) "The Spanish Turn: The Discovery of Spanish Art in the United States, 1887-1920”. In QuodBoch, Esmee (ed). Collecting Spanish Art in the United States. College Park. PA. Pennsylvania State University Press.

KROPP, Phoebe S.

2006 California Vieja. Culture and Memory in a Modern American Place. Berkeley - Los Angeles. University of California Press

LEVKOFF, Mary L.

2008 Hearst the Collector. New York. Abrams.

LONGSTRETH, Richard W.

1983 On the Edge of the World. Cambridge (MA). MIT Press.

LOVATO, Andrew Leo

2006 Santa Fe Hispanic Culture. Preserving Identity in a Tourist Town. Albuquerque. University of New Mexico Press.

LuMmIs, Charles

1912 The Spanish Pioneers. Chicago. McClurg.

MARTínez Ruiz, María José

2008 La enajenación del patrimonio en Castilla y León (1900-1936). Valladolid. Junta de Castilla y León

2009 "La diplomacia española y estadounidense y su relación con el comercio de antigüedades en la primera mitad del siglo XX". Goya. Madrid. $\mathrm{n}^{\mathrm{o}} 329$, pp. 328-351.

MCKINLEY, William

1900 Speeches and Addresses of William McKinley. New York. Doubleday \& McClure.

MERINO De CÁCERES, José Miguel

1985 "En el cincuentenario de la muerte de Arthur Byne". Academia. Madrid. $\mathrm{n}^{\mathrm{o}}$ 61, pp. 147-174

NiETO-PhILIPS, John M.

2008 The Language of Blood: The Making of Spanish-American Identity in New Mexico. Albuquerque. University of New Mexico Press.

NorTOn, Charles Eliot (ed)

1893 Letters of James Russell Lowell. New York. Harper \& Bros. OFFNER, John L.

1992 An Unwanted War: The Diplomacy of the United States and Spain over Cuba, 1895-1898. Chapel Hill. University of North Carolina Press.

1997 "La política norteamericana y la guerra de hispano-cubana". En FusI, Juan - NiÑo, Antonio (eds.). Visperas del 98: Orígenes y antecedentes de la crisis del 98. Madrid. Biblioteca Nueva, pp. 195-204. 
PAYNe, Stanley

2010 "The Reencounter between Spain and the United States after 1898". En SuÁREZ-ZuloAgA, Ignacio (ed.). When Spain Fascinated America. Madrid. Fundación Zuloaga, pp. 11-25

PISANO, Donald G.

1983 A Leading Spirit in American Art: William Merritt Chase, 1849-1916. Seattle. Henry Art Gallery.

ROBERTS, David

1837 Picturesque sketches in Spain taken during the years 1832 and 1833. London. Hodgson and Graves.

Roof, Katherine Metcalf

1917 Life and Art of William Merritt Chase. New York. Charles Scribners and Sons.

SÁNCHEZ MANTERO, Rafael

1994 “La imagen de España en los Estados Unidos”. En SÁnchez ManTERo, Rafael - Macarro Vero, José Manuel - Álvarez Rey, Leandro (eds.). La imagen de España en América, 1898-1931. Sevilla. Escuela de Estudios Hispano-Americanos, pp. 38-39.

2001 "Viajeros y diplomáticos en el reinado de Fernando VII. El descubrimiento de España por los americanos". Ayer. Revista de Historia Contemporánea. Madrid. no 41, pp. 141-160.

SCHMIDT-NowARA, Christopher

2006 The Conquest of History. Spanish Colonialism and National Histories in the Nineteenth Century. Pittsburgh. University of Pittsburgh Press.

2008 "Spanish Origins of the American Empire: Hispanism, History, and Commemoration, 1898-1915" International History Review. Burnaby. no 30 , pp. 32-51.

2010 "A New Imperial Past: The Spanish Empire in the United States after 1898". Comunicación presentada al congreso: "Eclipse of Empires: Colonial Resistance, Metropolitan Decline, and Imperial Crises in the XIX and XX Centuries", Universitat Pompeu Fabra, Barcelona, June 24, 2010. Versión digital: www.upf.edu/iuhjvv/pdf/schmidtnowara_barcelona 2010 paper.pdf

WALKer, Pierre A. - ZACHARIAS, Greg W.

2006 The Complete Letters of Henry James. Lincoln. University of Nebraska Press.

WEBER, David J.

1992 The Spanish Frontier in North America. New Haven. Yale University Press.

WEINBERG, H. Barbara

2003 "William Merritt Chase and the American Taste for Painting". WILSON, Chris Magazine Antiques. New York. no 163: 4, pp. 92-101.

1997 The Myth of Santa Fe. Creating a Modern Regional Tradition. Albuquerque. University of New Mexico Press. 